\title{
Ramón de la Fuente Muñiz, buillder of modern psychiatry in Mexico and Latin America. On the centenary of his birth
}

\author{
César Campos-Farfán*
}

World Association for the History of Psychiatry, Michoacán, Mexico

\begin{abstract}
This 2021 marks the centenary of Dr. Ramón de la Fuente Muñiz (1921-2006) birth, a prominent member of our University and creator of institutions. In this brief communication, without pretending for it to be a biography, we will try to commemorate this event, with a judicious and objective account of the most outstanding aspects of his life and work.
\end{abstract}

KEY WORDS: Ramón de la Fuente. Centenary. Psychiatry. History of medicine.

\section{Ramón de la Fuente Muñiz, forjador de la psiquiatría moderna en México y Latinoamérica. En el centenario de su nacimiento}

\section{Resumen}

Este 2021 se cumple el centenario del natalicio del doctor Ramón de la Fuente Muñiz (1921-2006), universitario y creador de instituciones. En esta breve comunicación, sin la pretensión de ser una biografía, proponemos conmemorar dicho acontecimiento, con un recuento juicioso y objetivo de los aspectos más sobresalientes de su vida y obra.

PAlabras clave: Ramón de la Fuente. Centenario. Psiquiatría. Historia de la medicina.

\section{Preface}

Ramón de la Fuente Muñiz, teacher of generations and creator of the national psychiatric school, was born in Mexico City on August 29, 1921. He studied at the Faculty of Medicine of the National Autonomous University of Mexico (UNAM - Universidad Nacional Autónoma de México), our beloved alma mater, between 1939 and 1944. In the latter year he presented the thesis entitled El psicodiagnóstico de Rorschach: aplicación en la clínica (Rorschach's psycho-diagnosis: clinical application), a 134-page document, which, in addition to granting for him the degree, preludes an interesting and more than fruitful career as a teacher, academic and researcher; without forgetting, of course, about his facet as founder of the most important psychiatric institution in Latin America.

He was a Samuel Ramírez Moreno (1898-1951) student, who supported him so that once he completed his undergraduate training, he could undertake a postgraduate course in neuropsychiatry at Bishop Clarkson Memorial Hospital, in Omaha, Nebraska, between 1944 and 1946, under the tutelage of Dr. Abraham. E. Bennett (1899-1985), and subsequently a brief stay at the historic Belleveu Hospital Center in New York City (1946).

When he returned to Mexico, the care and teaching landscape of psychiatry was drastically changing; there was a succession of intermingled events that he
Correspondence:

${ }^{*}$ César Campos-Farfán

E-mail: nocup@ hotmail.com
Gac Med Mex. 2021;157:320-324 Contents available at PubMed www.gacetamedicademexico.com 0016-3813/C 2021 Academia Nacional de Medicina de México, A.C.. Published by Permanyer. This is an open access article under the CC BY-NC-ND license (http://creativecommons.org/licenses/by-nc-nd/4.0/). 
himself would give continuity to. Since 1944, Raúl González Enríquez (1906-1952) efficiently organized the Neuropsychiatry Unit of recently-created Mexican Institute of Social Security; first as a department attached to Clinic 11 and then, since 1946, independently, at 110 Naranjo street, Santa María la Ribera neighborhood.

Subsequently, between 1948 and 1950, González Enríquez organized the first course in the psychiatry specialty at the General Asylum of Mexico, known as La Castañeda. Then, in 1951, the UNAM School of Graduates formally opened the University Psychiatry Course, with Dr. González Enríquez as its first mentor (only for the years 1951 and 1952). ${ }^{2,3}$

González Enríquez had also invited Erich Fromm, who had resided in Mexico since 1949, to be part of his course at La Castañeda Asylum, where he gave a seminar on dynamics of the subconscious. Overcoming bureaucratic obstacles, Fromm was appointed extraordinary professor at UNAM's Faculty of Medicine. This way, the Mexican Psychoanalytic Studies Group could be organized, which was self-appointed as the "original group", composed of 13 aspiring doctors: Raúl González Enríquez, Aniceto Aramoni, Guillermo Dávila García, Jorge Derbez Muró, Abraham Fortes Rudoy, José F. Díaz y Díaz, Francisco Garza, Arturo Higareda Loyden, Armando Hinojosa, Alfonso Millán Maldonado, Jorge Silva García, Jorge Manuel Velasco Alzaga and Ramón de la Fuente Muñiz. ${ }^{4}$

On the other hand, around that time, Ramón de la Fuente married Beatriz Ramírez Aguirre (1929-2005), daughter of his mentor and Mrs. Piedad Aguirre Argüelles. Later known as Beatriz de la Fuente, she was a distinguished university member, emeritus researcher, director of the Institute for Esthetic Research at UNAM (1980-1986) and the first woman to become a member of the National College (1985). ${ }^{5}$ On September 5, 1951, Juan Ramón de la Fuente Ramírez, who in recent years was Secretary of Health (1994-1999) and served as rector of UNAM (1999-2007), was born

Two important events marked Ramón de la Fuente Muñiz's life and subsequent professional development: on April 12, 1951, Dr. Samuel Ramírez Moreno, his father-in-law, with whom he had collaborated since his return from the United States, died; 6 and on October 18, 1952, Raúl González Enríquez, founder and president of the Psychiatric Association of Latin America, disappeared in the Tecolutla River. Without González Enríquez, Fromm's favorite disciple, the socalled "12 apostles" remained.
The Psychiatry Specialty Chair was assumed by Guillermo Dávila García (1953-1968), who was followed by Ramón de la Fuente Muñiz (he was a professor since 1961). From 1968 to the year of his death, professor de la Fuente took care of it brilliantly. Over time, this Chair was transformed into the Department of Medical Psychology, Psychiatry and Mental Health of UNAM's Faculty of Medicine.

\section{A brilliant career}

During the decades of 1950 and 1960, the restless and intelligent psychiatrist gradually built his destiny, shaped and gave a new perspective to psychiatry in Mexico in all its fields.

Ramón de la Fuente Muñiz served at the Children's Hospital of Mexico, where he founded the Mental Health Department (as well as at the Spanish Hospital, where in 1968 he was still head of the Psychiatry Department). In April 1951, he published his first work in the journal of the same hospital. ${ }^{7}$ In 1955, his first international article appeared. ${ }^{8}$ In 1959, he published his first book: Psicología Médica (Medical Psychology), published by Fondo de Cultura Económica, with 22 reprints (a second edition in 1992 with eight reprints). In the latter year, he was admitted to the National Academy of Medicine of Mexico.

He consolidated his position of commitment to the University. As Doctor Heinze well says: "for many decades, the Professor's name was merged with that of UNAM." $\mathrm{He}$ was member of the Faculty of Medicine Technical Council and, from 1970 to 1980, member of UNAM's Governing Board. In 1983, he was appointed professor emeritus; two years later, he was granted an honorary doctorate. In 1990, he was bestowed the National University Award in the Area of Natural Sciences Teaching. In October 2004, the UNAM Faculty of Medicine awarded him the "Dr. Ignacio Chávez Medal". 9

Dr. Ramón de la Fuente was member of the Mexican Society of Neurology and Psychiatry, founded in 1939, whose official publication was the Archivos de Neurología y Psiquiatría de México (Archives of Neurology and Psychiatry of Mexico) journal. Despite the apparently good "relationship" between both disciplines, professor de la Fuente found it more appropriate for psychiatry to walk and develop by itself, and thus he decided to found the Asociación Psiquiátrica Mexicana, A.C. (Mexican Psychiatric Association, NPO). On Thursday, March 31, 1966, in the classroom of La Castañeda General 
Asylum central ward, at 12:30 hours, with attendance of 142 psychiatrists, the constitutive meeting was held. The assembly was conducted by Doctors Ramón de la Fuente, in his capacity as secretary of the organizing committee, Guillermo Calderón Narváez, from the same committee, as well as by Mario Fuentes Delgado and Javier Garciadiego, director and deputy director, respectively, of the institution. After preliminary recitals were briefly expounded, the provisional statutes were read and the first board of directors was elected, which would comprise the periods from April 1966 to the same month in $1968 . .^{10} \mathrm{He}$ was elected as first president of the Mexican Psychiatric Association, NPO and his administration lasted until 1969 when he organized and chaired the first National Meeting of this Association (Mexico City), where he handed over the baton to Dr. Guillermo Calderón Narváez for the 1970-1971 biennium. So far, 26 biannual congresses have been held, the last in 2019 in the city of Monterrey, Nuevo León.

In 1972, Ramón de la Fuente organized the Mexican Council of Psychiatry. On April 4 of that year, he entered the National College, introduced by Michoacán native doctor Manuel Martínez Báez, and delivered the lecture "Medicine, humanism and human sciences".

Five years after its foundation, the Mexican Psychiatric Association and the Mexican Society of Neurology and Psychiatry hosted the $5^{\text {th }}$ World Congress of Psychiatry, held in Mexico City in 1971. Professor de la Fuente chaired the organizing committee: ${ }^{11}$

\begin{abstract}
In his opening speech he made a brave denunciation of some abusive practices of psychiatry by some totalitarian regimes, which undoubtedly contributed to mobilizing international action. The World Health Organization invited him the following year to join the Committee of Experts that interviewed several dissidents who had been committed in the former Soviet Union. ${ }^{12}$
\end{abstract}

From that year and until 1976, Ramón de la Fuente Muñiz was vice president of the World Association of Psychiatry. From 1979 to 1983 he was vice president of the World Federation for Mental Health for Latin America.

\section{National Institute of Psychiatry}

Historical backgrounds of the Institute go back to the time when the nosocomial structure of the Mexican Institute of Social Security was projected. During its planning, in 1941, Dr. Raúl González Enríquez proposed the creation of a neuropsychiatric institute and it was agreed that at the moment it would only be a health care center. ${ }^{1}$ In 1950, during the works of the First World Congress of Psychiatry, Dr. Samuel Ramírez Moreno took to Paris, among others, the idea of transforming La Castañeda General Asylum into the National Institute of Neuropsychiatry. ${ }^{13}$ González Enríquez, who persisted in the idea of the institute, even motivated colleagues from Central America, after the First Congress of the Psychiatric Association of Latin America, in 1951, in order for the possibility of the Institute of Mental Health of Central America and Panama to be proposed in 1958, which also remained just as an initiative. On March 29 and 30,1958 , representatives of the six countries gathered in Managua, Nicaragua (original document, courtesy of Dr. Ramón Alcerro Castro, in possession of the author).

In 1970, under the seal of the National Academy of Medicine, Ramón de la Fuente Muñiz released his second book: Aspectos clínicos del alcoholismo: estudios sobre 62 casos (Clinical aspects of alcoholism: studies on 62 cases). ${ }^{14}$ Shortly after, in 1972, the Mexican Center for Drug-Dependence Studies, where preventive, curative and rehabilitation aspects related to the use of addictive substances were addressed, was created.

During this period, in 1973, Ramón de la Fuente Muñiz served as president of the National Academy of Medicine of Mexico (honorary member since 1992). Also from those days and until 2000 he was an advisor to the World Health Organization in the area of mental health. He participated in the working groups for the integration of the International Classification of Diseases 1990 tenth revision (ICD-10).

Between 1977 and 1980, Ramón de la Fuente was director of the Mental Health section of the Ministry of Health and Assistance during José López Portillo's six-year term (1976-1982), from whom he received the necessary support in order for the Mexican Center for Mental Health Studies to be established in June 1978, replacing the Mexican Center for Drug-Dependence Studies, whereby the center expanded its coverage in terms of care for patients with psychiatric problems. In December 1979, the Official Gazette of the Federation published the presidential decree that gave life to the Mexican Institute of Psychiatry, replacing the Mexican Center for Mental Health Studies. It was until 1988 that the Official Gazette published the corresponding decree and Ramón de la Fuente was appointed director general, officially, for two periods (1988-1998), although in practice he was director 
since 1972 with the opening of the Mexican Center for Drug-Dependence Studies. In honor of its founder, on May 26, 2000, it was named National Institute of Psychiatry "Dr. Ramón de la Fuente Muñiz".

During his long career as a teacher and builder of institutions, he published approximately 170 works. In this sense, his activity was not less fruitful. He was editor of Revista Mexicana de Psicología, Psiquiatría y Psicoanálisis (Mexican Journal of Psychology, Psychiatry and Psychoanalysis), supported by Fondo de Cultura Económica, a publishing house where for more than 30 years he directed Colección Psicología, Psiquiatría y Psicoanálisis (Psychology, Psychiatry and Psychoanalysis Collection). He founded Revista Psiquiatría (Psychiatry Journal), the Mexican Psychiatric Association dissemination publication, and Salud Mental (Mental Health), of the National Institute of Psychiatry, which for many years has been considered one of the most influential in Latin America. In addition, he was member of the editorial boards of several international specialty journals.

Among his books, El pensamiento vivo de Erich Fromm (Erich Fromm's living thought) (1989), ${ }^{15}$ Nuevos caminos de la Psiquiatría (New paths of psychiatry) (1990), ${ }^{16}$ La patología mental y su terapéutica (Mental pathology and its therapeutics) (two volumes, 1997), ${ }^{17}$ Salud mental en México (Mental health in Mexico) (1997), ${ }^{18}$ Biología de la mente (Biology of the mind) (1998) ${ }^{19}$ and Aportaciones recientes de la biología a la psiquiatría (Recent contributions of biology to psychiatry) (2003). ${ }^{20}$

Ramón de la Fuente Muñiz received many well-deserved distinctions, some already mentioned. In 1988, the Ministry of Health, through the General Health Council, awarded him the "Eduardo Liceaga" Decoration, which is the highest recognition the nation grants in the area of medicine. In 1993, on the fiftieth anniversary of the Ministry of Health, together with other nine doctors, he received from the President of the Republic a medal for his contributions to Mexican medicine. In turn, the American Psychiatric Association awarded him the "Simón Bolívar" Medal.

He passed away on March 31, 2006 at age 84.

Ramón de la Fuente Muñiz's biography is yet to be written; in this attempt, many facts remained pending in the inkwell. It is a debt that Mexican science owes to this preeminent and more than generous teacher. When the time has come, with the required serenity, it will then be possible for a fair balance in proportion to his actions to be made; thus, understanding the significance and magnitude of his work will be possible. For now, the founder of the institute that bears his name, with true justice and in accordance with his deeds, is considered the most influential psychiatrist in Mexico and Latin America of the second half of the $20^{\text {th }}$ century. With the preceding lines, we wish to remember the Professor on the centenary of his birth.

In remembrance of the anniversary of his sad passing, the Psychiatrist's Day was celebrated for the first time in Mexico in 2019.

\section{Funding}

None.

\section{Conflict of interests}

None.

\section{Ethical disclosures}

Protection of human and animal subjects. The author declares that no experiments were performed on humans or animals for this research.

Confidentiality of data. The author declares that no patient data appear in this article.

Right to privacy and informed consent. The author declares that no patient data appear in this article.

\section{References}

1. González-Enríquez R. La neuropsiquiatría en el régimen de seguridad social en México. Rev Latinoam Psiquiatr. 1952;1:54-59.

2. Pérez-Rincón H. Breve historia de la psiquiatría en México. Mexico: Instituto Mexicano del Petróleo; 1995.

3. Calderón-Narváez G. Las enfermedades mentales en México, desde los mexicas hasta el final del milenio. Mexico: Trillas; 2002.

4. Rocha-Guzmán G. Las instituciones psicoanalíticas en México. Un análisis sobre la formación de analistas y sus mecanismos de regulación [Master's thesis on social psychology of groups and institutions]. Mexico: Universidad Autónoma Metropolitana Xochimilco; 1998.

5. In Memoriam. Beatriz de la Fuente (1929-2005). An Inst Investig Estet. $2005 ; 87$.

6. Ruiz-López I. Samuel Ramírez Moreno (1898-1951). En el centenario de su nacimiento. Fundador de la neuropsiquiatría en México. Arch Neurocien Mex. 1998;3:59-63.

7. De la Fuente R, Zúñiga $C$. Efecto del ácido glutámico sobre la función intelectual de los niños mentalmente deficientes; revisión de la literatura y estudio de 36 casos. Bol Med Hosp Infant Mex. 1951; 8:160-172.

8. De la Fuente-Muñiz R. Fromm's approach to the study of personality. Psychiatr Res Rep Am Psychiatr Assoc. 1955;2:7-14.

9. Heinze G. In memoriam. El maestro de la Fuente: el universitario y promotor de la psiquiatría en México. Salud Mental. 2006;29:1-4.

10. Dr. Ramón de la Fuente Muñiz. Presidente fundador de la Asociación Psiquiátrica Mexicana. Médicos de México. 2009; year 7 (107 special edition):16-18.

11. De la Fuente R, Weisman MN, editors. Psychiatry: proceedings of the $\mathrm{V}$ World Congress of Psychiatry, Mexico, D. F., 25 November-4 December 1971. The Netherlands: Excerpta Medica; 1973. 
12. Heinze G, Pérez-Rincón H. In Memoriam. Ramón de la Fuente (19212006). Salud Mental. 2006;29(2):1-3.

13. Ramírez-Moreno S. La asistencia psiquiátrica en México. Mexico: Secretaría de Salubridad y Asistencia; 1950.

14. De la Fuente R. Aspectos clínicos del alcoholismo: estudios sobre 62 casos. Mexico: Academia Nacional de Medicina; 1970

15. De la Fuente-Muñiz R. El pensamiento vivo de Erich Fromm. Mexico: Fondo de Cultura Económica; 1989

16. De la Fuente R. Nuevos caminos de la psiquiatría. Mexico: Fondo de Cultura Económica (Colección de Psicología, Psiquiatría y Psicoanálisis); 1990.
17. De la Fuente $R$, coordinator. La patología mental y su terapéutica. Mexico: Fondo de Cultura Económica (Colección de Psicología, Psiquiatría y Psicoanálisis); 1997.

18. De la Fuente R, Medina-Mora ME, Caraveo J. Salud mental en México. Mexico: Fondo de Cultura Económica (Colección de Psicología, Psiquiatría y Psicoanálisis); 1997.

19. De la Fuente R, Álvarez Leefmans FJ, editors. Biología de la mente. Mexico: El Colegio Nacional/Fondo de Cultura Económica (Colección de Psicología, Psiquiatría y Psicoanálisis); 1998.

20. De la Fuente R, coordinator. Aportaciones recientes de la biología a la psiquiatría. Mexico: El Colegio Nacional; 2003. 